\title{
Alloying Behaviour and Microstructural Changes of a Ti-10\%Mo-10\%Cr Alloy on Sintering Process
}

(Sifat Pengaloian dan Perubahan Mikrostruktur Aloi Ti-10\%Mo-10\%Cr ke atas Proses Sinter)

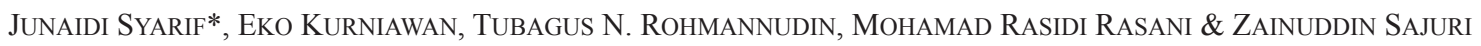

\begin{abstract}
This study aimed to investigate the effects of element diffusion on the alloying behaviour and microstructure of a Ti-10\%Mo$10 \% \mathrm{Cr}$ alloy during sintering and furnace cooling. A theoretical calculation of the average diffusion distance for each element was performed to predict the alloying behaviour during sintering and furnace cooling. The Ti-10\%Mo-10\%Cr alloy was fabricated using a blended element powder metallurgy approach. Micrograph of the samples after sintering showed bright-circle structures and significantly decreased equiaxed structures. The number of plate-like structures increased with prolonged sintering time. Microstructural changes occurred because of element diffusion resulting from the prolonged sintering time. Moreover, the diffusion distance of each element also increased with prolonged sintering time. Although elements can sufficiently diffuse during both sintering and furnace cooling, the diffusion distance during sintering was considerably higher than that during furnace cooling for all elements. The diffusion distances of Cr and Mo were the highest and lowest, respectively, during sintering and furnace cooling. This study showed that alloying behaviour mostly occurred during sintering and was controlled by the diffusion of Mo atoms.
\end{abstract}

Keywords: Diffusion; microstructure; powder metallurgy; sintering; Ti alloy

\section{ABSTRAK}

Kajian ini bertujuan untuk mengkaji kesan peresapan unsur terhadap kelakuan pengaloian dan mikrostruktur pada aloi Ti-10\%Mo-10\% Cr semasa sinteran dan penyejukan relau. Pengiraan secara teori terhadap jarak peresapan purata bagi setiap unsur dilakukan untuk meramal kelakuan pengaloian semasa sinteran dan penyejukan relau. Aloi Ti-10\%Mo$10 \% \mathrm{Cr}$ telah direka menggunakan pendekatan metalurgi serbuk unsur sebati. Mikrograf sampel selepas pensinteran menunjukkan struktur bulatan-terang dan struktur sama paksi yang menurun secara ketara. Bilangan struktur seperti plat meningkat dengan memanjangkan masa pensinteran. Perubahan mikrostruktur berlaku disebabkan penyebaran unsur yang dihasilkan semasa pensinteran yang berpanjangan. Selain itu, jarak resapan bagi setiap elemen juga meningkat dengan masa pensinteran berpanjangan. Walaupun unsur-unsur boleh cukup meresap semasa sinteran dan penyejukan relau, jarak resapan semasa sinteran adalah lebih tinggi daripada semasa penyejukan relau untuk semua unsur. Jarak peresapan Cr dan Mo masing-masing yang tertinggi dan terendah, semasa sinteran dan penyejukan relau. Kajian ini menunjukkan bahawa kelakuan pengaloian kebanyakannya berlaku semasa sinteran dan dikawal oleh resapan atom Mo.

Kata kunci: Aloi Ti; metalurgi serbuk; mikrostuktur; pensinteran; peresapan

\section{INTRODUCTION}

In recent years, $\mathrm{BCC}(\beta)$ type Ti alloys have received considerable attention for biomaterial applications because of their specific strength, excellent corrosion resistance, biocompatibility and low elastic modulus of the $\beta$-Ti alloys (Leyens \& Peters 2003). Niinomi (2003) also showed that Ti alloys have excellent biocompatibility, especially for dental applications. Moreover, Oliveira and Guastaldi (2009) reported that $\mathrm{Ti}$ alloys are promising biomaterials because they have good corrosion resistance. Since the biocompatibility of alloys is important, therefore the safest alloying elements ( $\mathrm{Nb}, \mathrm{Ta}, \mathrm{Zr}, \mathrm{Mo}$ and $\mathrm{Sn}$ ) for the human body must be selected for the development new $\beta$-type titanium alloys (Niinomi 2003, 2002). However, the biomaterial applications of titanium are limited by the high cost of this element (Carman et al. 2011). Moreover, Niinomi (2003) stated that materials for dental application that are often fabricated through casting are difficult to be treated because of inaccurate high-precision products.

On the other hand, inexpensive powder metallurgy (PM) techniques can also be used to fabricate Ti alloys (Carman et al. 2011). Fujita et al. (1996) demonstrated that the Ti-4.5A1-3V-2Fe-2Mo alloy that is fabricated by a blended element powder metallurgy (BEPM) exhibits superior properties over Ti-6Al-4V alloy such as high sinterability, fine microstructure, excellent mechanical properties and good cold workability. Then, Yang et al (2011) noted that the densification of sintered product can be achieved by the BEPM process. In BEPM, powder 
elements are blended with a master element, cold pressed and then sintered to a higher density (Hagiwara \& Emura 2003). Moreover, the PM technique can fabricate parts with near net-shapes at a large scale and with relatively low cost (Abkowitz et al. 2015).

In our previous work, authors developed a new $\beta$-Ti alloy by BEPM and showed that the alloy exhibits a single $\beta$-phase after sintering and solution treatment with quenching (Syarif et al. 2013, 2008). However, the diffusion behavior of the alloying element during sintering and furnace cooling remains unclear. In this study, the effect of element diffusion on the alloying behavior and microstructural change was investigated on a Ti- $10 \% \mathrm{Mo}-$ $10 \% \mathrm{Cr}$ alloy that is subjected to sintering and furnace cooling.

\section{MATERIALS AND METHODS}

A Ti-10\%Mo- $10 \% \mathrm{Cr}$ alloy was used as the specimen in this study. In our previous work, the alloy showed a single $\beta$ phase after sintering at $1573 \mathrm{~K}$ for $14.4 \mathrm{ks}$ and solution treatment at $1573 \mathrm{~K}$ for $1.8 \mathrm{ks}$ (Syarif et al. 2013). Commercially pure $\mathrm{Ti}, \mathrm{Mo}$, and $\mathrm{Cr}$ powders were used as raw materials. All of the powders were supplied by Alfa Aesar (USA). Table 1 shows the purities and particle sizes of the powders used.

Ti powder as the master element was mechanically blended with $10 \% \mathrm{Mo}$ and $10 \% \mathrm{Cr}$ as the alloying element powders for $3.6 \mathrm{ks}$. The blended powder was loaded into a die cavity with a diameter of $10 \mathrm{~mm}$ and compressed by

TABLE 1. Particle size and purity of powders used

\begin{tabular}{ccc}
\hline Element & Particle size/ mesh & Purity $/ \%$ \\
\hline $\mathrm{Ti}$ & -325 & 99.0 \\
$\mathrm{Mo}$ & -170 & 99.5 \\
$\mathrm{Cr}$ & -325 & 99.0 \\
\hline
\end{tabular}

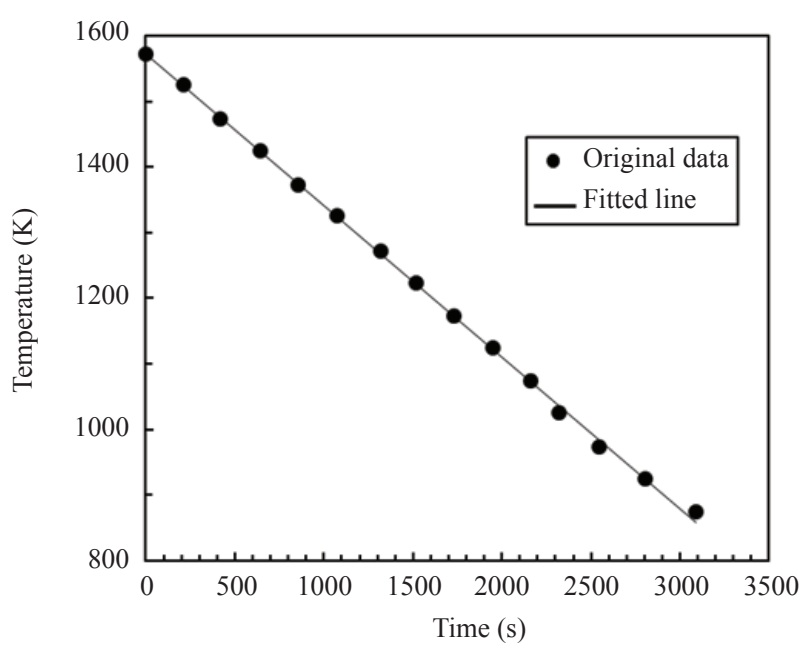

FIGURE 1. Relation between temperature and time on furnace cooling from $1573 \mathrm{~K}$ to $873 \mathrm{~K}$ from experiment result in vacuum furnace. The fitted line is linear regression for calculating cooling rate $(\lambda)$ cold compaction under a pressure of $1000 \mathrm{MPa}$ for 3.6 $\mathrm{ks}$ at ambient temperature. The sample was sintered at $1573 \mathrm{~K}$ for $0.6 \mathrm{ks}$ to $14.4 \mathrm{ks}$ and then furnace-cooled under an argon gas atmosphere after achieving vacuum conditions. In the furnace, the cooling rate $(\lambda)$ was approximately $0.23 \mathrm{~K} / \mathrm{s}$ when cooled from $1573 \mathrm{~K}$ to $873 \mathrm{~K}$ (Figure 1).

The microstructure of the alloy was observed by optical microscope and scanning electron microscope (SEM). Samples for microstructural observation were etched using Kroll's reagent. The distribution of elements in the sample was analyzed using SEM-energy dispersive $\mathrm{X}$-ray spectroscopy (EDS). Phase characterization was performed using X-ray diffractometry (XRD) with $\mathrm{Cu}-\mathrm{K} \alpha$ radiation. The phase evolution during furnace cooling was predicted using commercial software (JMatPro ${ }^{\mathrm{TM}}$ ).

\section{RESULTS AND DISCUSSION}

\section{MICROSTRUCTURAL CHANGES IN THE TI-10\%MO-10\%CR ALLOY}

Figure 2 shows the microstructure of the Ti-10\%Mo$10 \% \mathrm{Cr}$ alloy. In the $1.8 \mathrm{ks}$-sintered sample, bright-circle structures, equiaxed structures and pores were observed. Equiaxed structures were shown in the vicinity of the bright-circle structures, whereas needle-like structures were located far from the bright-circle structures. The needle-like structures indicate the presence of a dual-phase structure in the $14.4 \mathrm{ks}$-sintered sample. The formation of the needle-like structures was due to sympathetic nucleation, as reported by Lütjering and Williams (2007), the hep $(\alpha)$ phase will nucleate and grow within $\beta$ grains and along $\beta$ grain boundaries and $\alpha+\beta$ lamella will be formed during furnace cooling from the $\beta$ phase region. The volume fraction of all structures changed as the sintering time was increased. As shown in Figure 3, the volume fraction of each structure changed as a function of the sintering time. The amount of bright-circle and equiaxed structures decreased as the sintering time increased. The volume fraction of the pores slightly increased, although interparticle bonding occurred during sintering. Shewmon (1989) stated that the pores were formed because of the Kirkendall effect. The amount of the bright-circle and equiaxed structures decreased because of the formation of needle-like structures during sintering. The alloying behavior and the interparticle bonding of the blended pure metallic powders were enhanced by diffusion of elements during sintering.

To further analyze the alloying behavior, the samples were subjected to XRD. The XRD diffractograms of the samples are shown in Figure 4. The XRD diffractogram of the green compact is also shown. In this figure, the peaks of the pure Mo and Cr powders disappeared after $0.6 \mathrm{ks}$ of sintering and $\beta$ phase peaks can be observed alongside the peaks corresponding to the $\alpha$ phase in the alloy. The peak intensity of the $\alpha$ phase increased as the sintering time was increased. This result indicates that the increase in the volume fraction of needle-like structures can be 

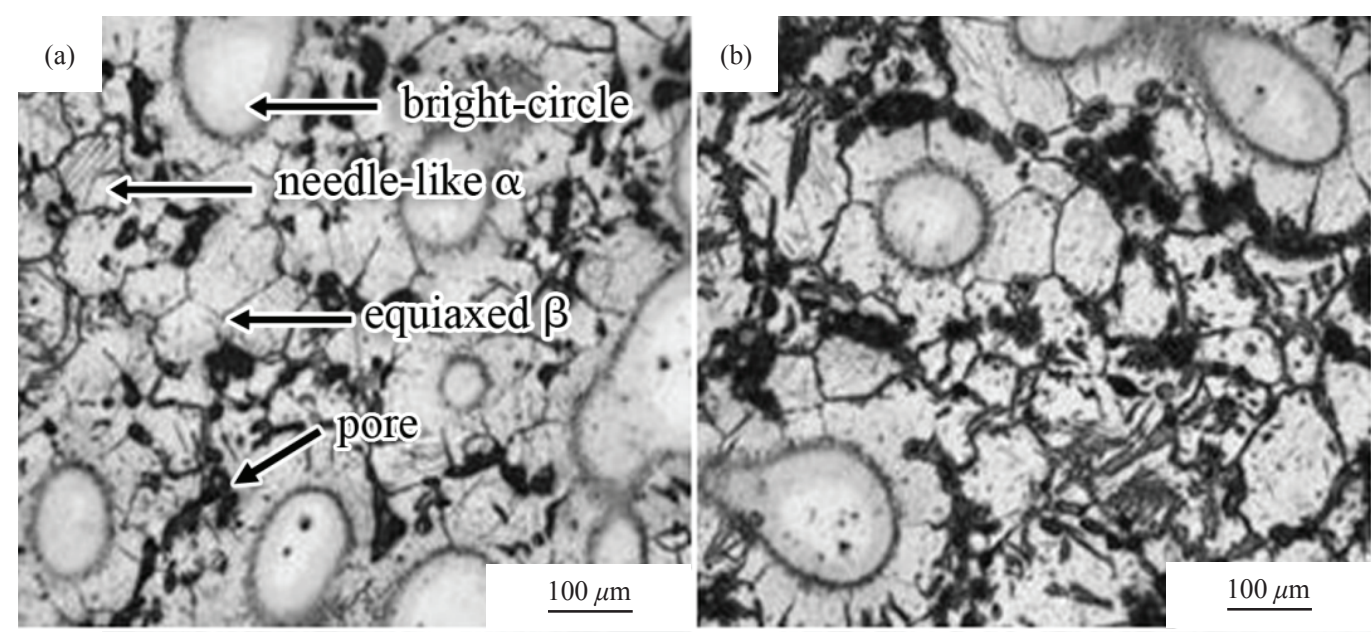

(c) 51 -
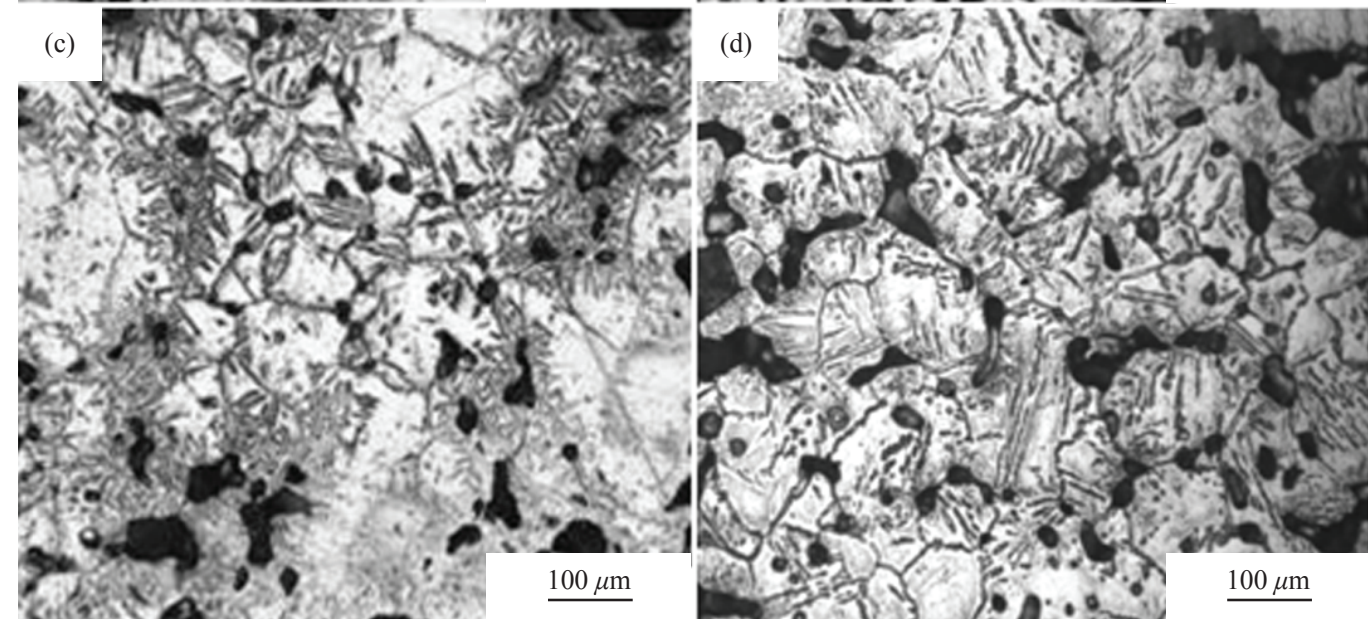

FIGURE 2. Micrograph of the samples after sintering at (a) $0.6 \mathrm{ks}$; (b) $1.8 \mathrm{ks}$; (c) $5.4 \mathrm{ks}$; and (d) $14.4 \mathrm{ks}$ and followed by furnace cooling

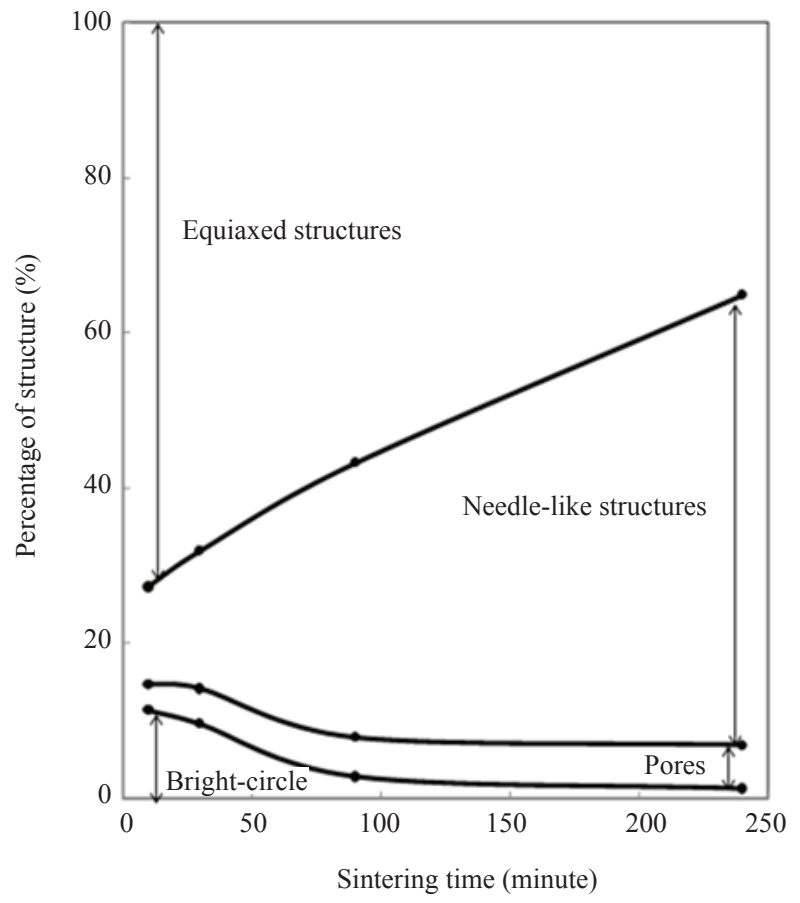

FIGURE 3. Schematic diagram of alloying behavior during sintering process and followed by furnace cooling

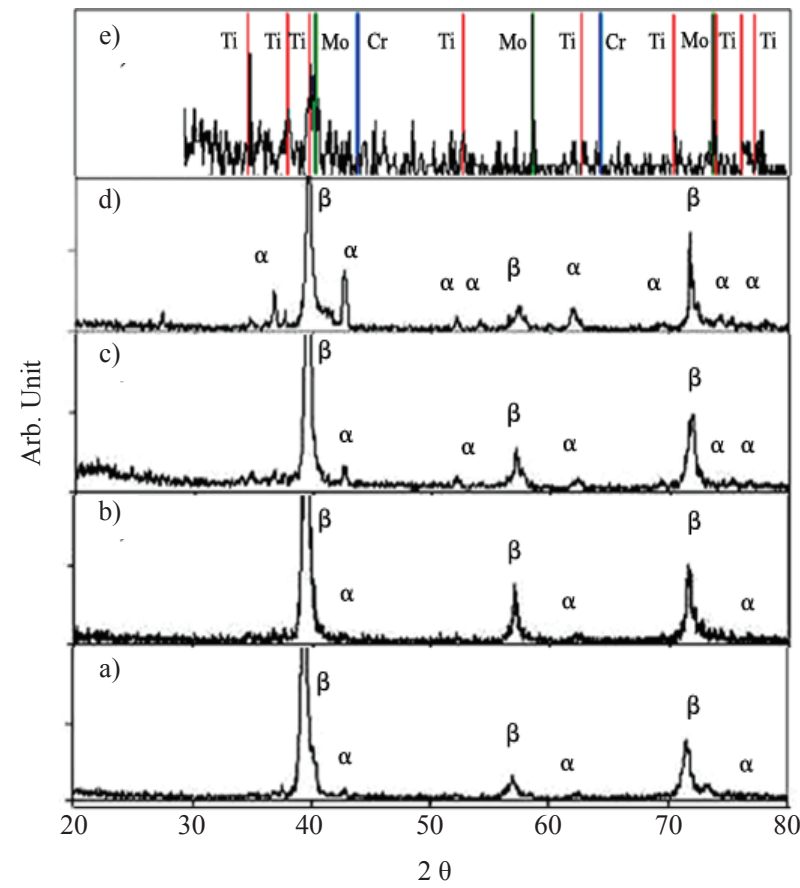

FIGURE 4. XRD diffactrograms of the (a) $0.6 \mathrm{ks}$; (b) $1.8 \mathrm{ks}$; (c) $5.4 \mathrm{ks}$; and (d) $14.4 \mathrm{ks}$ sintered sample and (e) green sample 
attributed to the formation of needle $\alpha$ structures in the sintered sample. Thus, the XRD results are consistent with the result depicted in Figure 3. Alloying of the blended pure powders occurred during sintering and furnace cooling, although the single $\beta$ phase was not obtained through this process.

\section{ALLOYING BEHAVIOR}

The atomic distribution and chemical concentration of all elements were examined by SEM-EDS to clarify the contribution of element diffusion to the alloying behavior. Figure 5 presents backscattered electron (BSE) images and mapping of element distribution of the sample sintered at $1573 \mathrm{~K}$ for $0.6 \mathrm{ks}$. Two microstructures were observed from the sample: The first was a bright-circle structure within a dark region (Figure 5(a)) and the other was a needle- like structure (Figure 5(b)). The bright-circle structure within the dark region was identical to the bright-circle and equiaxed microstructures shown in Figure 2(a). In the bright-circle structures, $\mathrm{Cr}$ atoms were uniformly distributed within the sample. Conversely, the distribution of Mo and Ti atoms exhibited the opposite distribution. $\mathrm{Ti}$ atoms were dispersed uniformly in the dark region, whereas Mo atoms were concentrated almost entirely in the bright-circle structures. The pure Mo powder was still not dissolved during this process. As shown in Figure 5(b), all atoms of the alloying elements were uniformly distributed within the needle-like structures.

Figure 6 shows the BSE images and mapping of element distribution of the $5.4 \mathrm{ks}$-sintered sample. The element distributions were also analyzed in the brightcircle and needle-like structures for the $5.4 \mathrm{ks}$-sintered sample. In the bright-circle structures, Mo atoms were
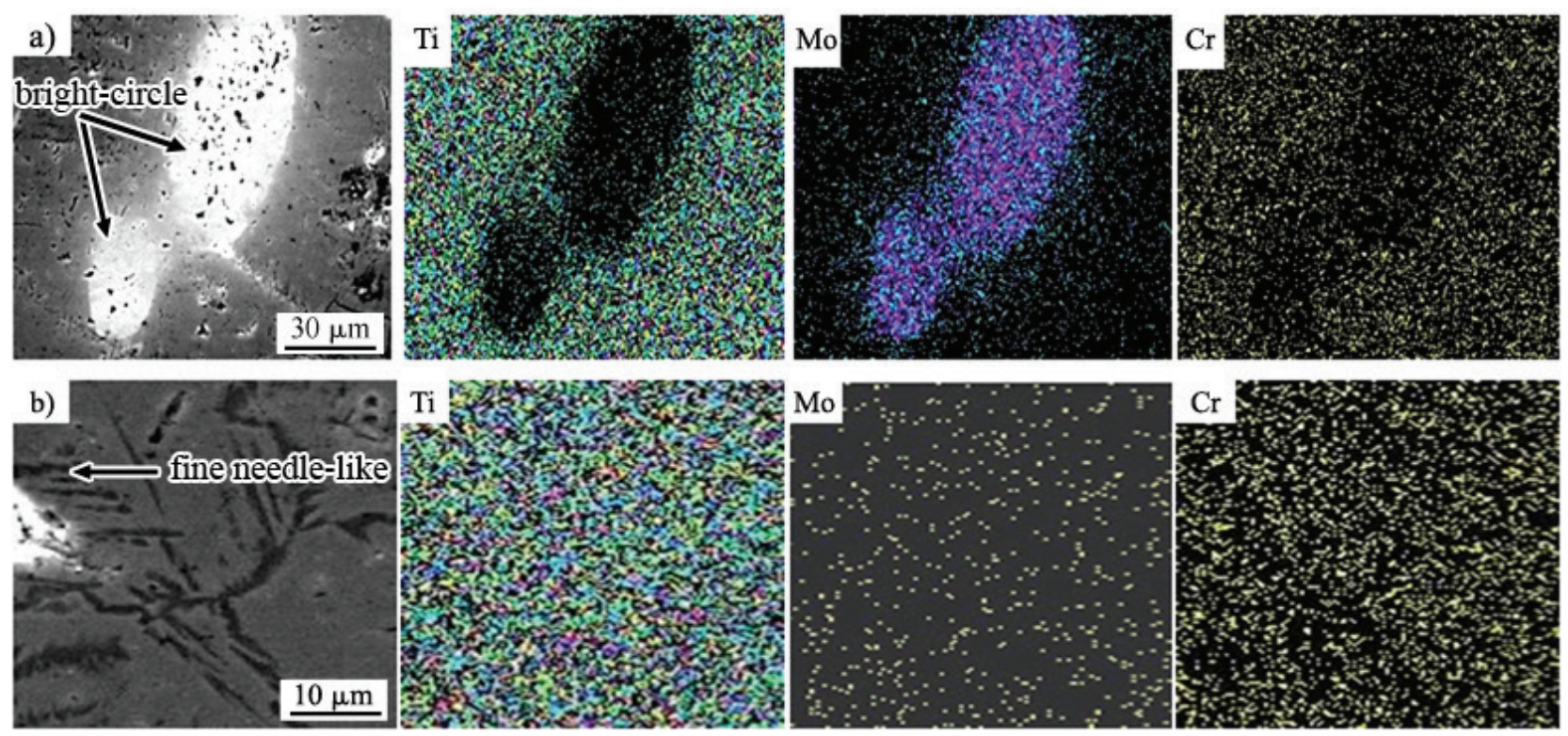

FIGURE 5. Mapping of element distribution in (a) bright circle structure and (b) fine needle-like structure for 0.6 ks sintered sample
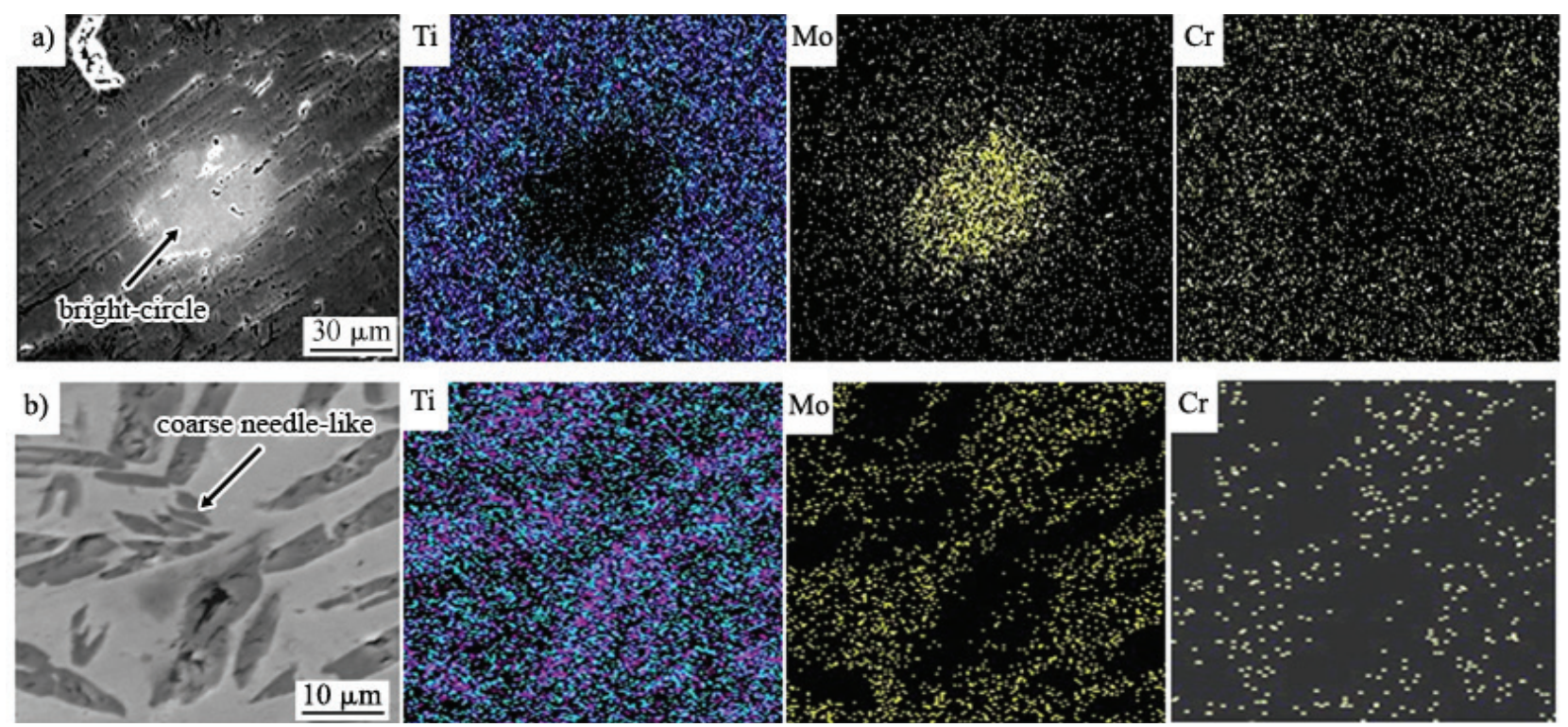

FIGURE 6. Mapping of element distribution in (a) bright circle structure and (b) coarse needle-like structure for 5.4 ks sintered sample 
still enriched in the bright-circle while Ti atoms were distributed in the dark region, although $\mathrm{Cr}$ atoms were well dispersed in the entire region. As shown in Figure 6(a), Ti atoms were completely distributed in all whitish and darkish areas. Conversely, Mo and $\mathrm{Cr}$ atoms were slightly enriched in the whitish area. Thus, the whitish area was believed to represent the $\beta$ phase because Mo and $\mathrm{Cr}$ atoms are the $\beta$ phase former.

Table 2 shows the average concentrations of the elements in all of the microstructures for the $0.6 \mathrm{ks}-$ and the $5.4 \mathrm{ks}$-sintered samples. The average concentration was measured by SEM-EDS to quantitatively analyze the element composition of the microstructures shown in Figures 5 and 6 . The average concentrations of $\mathrm{Cr}$ were almost identical to the designated $\mathrm{Cr}$ concentration of $10 \%$ in all microstructures. However, a significant difference in the Mo concentration was observed between the $0.6 \mathrm{ks}$ and 5.4 ks-sintered samples.

The bright-circle structures in both the $0.6 \mathrm{ks}-$ and 5.4 ks-sintered samples had higher Mo concentrations than the designated Mo concentration (10\%), although the Mo concentration decreased as the sintering time was increased. In contrast to the previous result, the average concentration of Mo in the needle-like structures increased as the sintering time was prolonged and almost reached the designated concentration. These results suggested that the alloying behavior has occurred during sintering and furnace cooling and that the diffusion of Mo atoms controlled the alloying behavior.

TABLE 2. Average concentrations of elements in microstructures of the $0.6 \mathrm{ks}$ - and the $5.4 \mathrm{ks}$-sintered samples

\begin{tabular}{clccc}
\hline \multirow{2}{*}{$\begin{array}{c}\text { Sintering } \\
\text { time }\end{array}$} & \multicolumn{1}{c}{ Microstructure } & \multicolumn{3}{c}{$\begin{array}{c}\text { Concentration of } \\
\text { element }\end{array}$} \\
\cline { 3 - 5 } & & $\mathrm{Ti}$ & $\mathrm{Mo}$ & $\mathrm{Cr}$ \\
\hline $0.6 \mathrm{ks}$ & Bright-circle structure & 74.1 & 16.7 & 8.1 \\
$0.6 \mathrm{ks}$ & Fine needle-like structure & 84.9 & 4.3 & 9.8 \\
$5.4 \mathrm{ks}$ & Bright-circle structure & 75.7 & 14.7 & 9.6 \\
$5.4 \mathrm{ks}$ & Coarse needle-like structure & 77.3 & 11.5 & 11.2 \\
\hline
\end{tabular}

\section{DIFFUSION OF ALLOYING ELEMENTS}

The diffusion of elements and the formation of needlelike structures were enhanced in the process, although the sample was sintered for a short time $(0.6 \mathrm{ks})$. Thus, element diffusion occurred not only during sintering at high temperatures but also during furnace cooling, because the cooling rate was sufficiently low.

The diffusion of element during sintering is usually expressed as follows (Kakani 2004).

$$
D_{e l}=D_{0} \exp [-Q /(R T)]
$$

where $D_{e l}$ is the diffusion coefficient of each element; $D_{0}$ is the temperature-independent pre-exponential factor; $Q$ is the activation energy; $R$ is the gas constant (8.31 $\mathrm{J} / \mathrm{mol} . \mathrm{K})$; and $T$ is the sintering temperature (1573 K). Table 3 summarizes the $D_{0}$ and $Q$ values for Ti, Mo and
Cr (Shackelford \& Alexander 2010). The phase prediction using JmatPro ${ }^{\mathrm{TM}}$ indicated that the sample was in the $\beta$ phase region during sintering at $1573 \mathrm{~K}$. Thus, the element diffusion was calculated based on the diffusion parameters in the $\beta$ matrix, yielding diffusion coefficients of $16.36 \times 10^{-13}, 8.3510^{-13}$ and $65.53 \times 10^{-13} \mathrm{~m}^{2} / \mathrm{s}$ for $\mathrm{Ti}$, $\mathrm{Mo}$, and $\mathrm{Cr}$, respectively. Consistent with the results of Nakajima and Koiwa (1991) the diffusion coefficient of Mo was the lowest compared to those of Ti and $\mathrm{Cr}$. This result can be attributed to the larger atomic size of Mo, which results in lower activation energy compared with Ti and Cr (Table 3).

TABLE 3. Diffusion data of elements

\begin{tabular}{cccc}
\hline Element & $\begin{array}{c}\text { Prefactor } \\
\mathrm{D}_{\mathrm{o}}\left(\mathrm{m}^{2} \cdot \mathrm{s}^{-1}\right)\end{array}$ & $\begin{array}{c}\text { Activation energy } \\
\mathrm{Q}\left(\mathrm{J}_{\mathrm{mol}}^{-1}\right)\end{array}$ & $\begin{array}{c}\text { Temperature } \\
\mathrm{T}(\mathrm{K})\end{array}$ \\
\hline$\alpha-\mathrm{Ti}$ & $8.6 \times 10^{-10}$ & 150306.12 & $973-1123$ \\
$\beta$ - $\mathrm{Ti}$ & $3.58 \times 10^{-8}$ & 130628.16 & $1173-1813$ \\
$\mathrm{Cr}$ & $5 \times 10^{-7}$ & 146956.68 & $1223-1873$ \\
$\mathrm{Mo}$ & $8 \times 10^{-7}$ & 180032.40 & $1173-1873$ \\
\hline
\end{tabular}

Shackelford \& Alexander 2010

Then, the average diffusion distance of each element can be estimated using Einstein's equation (Atkins \& De Paula 2006; Philibert 1991) as follows.

$$
\bar{x}_{s}=\sqrt{2 D_{e l} t_{s}}
$$

where is the linear distance travelled by diffusivity in one dimension; and $t_{\mathrm{s}}$ is the sintering time. The sintering times varied from 0.6 to $14.4 \mathrm{ks}$. Figure 7 shows the relation between the average diffusion distance and the sintering time $t_{\mathrm{s}}$. In general, the diffusion distance of all elements increased as the sintering time was increased.

On the other hand, the average diffusion distance of each element during furnace cooling was also calculated. Our simulation using JmatPro ${ }^{\mathrm{TM}}$ predicted that the $\beta$ phase decomposes into an $\alpha+\beta$ phase at temperatures of $773 \mathrm{~K}$ or below during furnace cooling. It is predicted that the diffusion of element will be very slow in the $\alpha$ phase and at temperature of $773 \mathrm{~K}$; thus, the average diffusion distance calculation was conducted in the range of $1573 \mathrm{~K}$ to $873 \mathrm{~K}$ and in the $\beta$ matrix.

Balluffi et al. (2005) defined the temperature during furnace cooling as follows,

$$
T=\frac{T_{0}}{1+\frac{t}{\lambda}}
$$

where $T_{0}$ and $\lambda$ are the initial temperature and cooling rate, respectively.

Furthermore, Shewmon (1989) explained that diffusion during cooling is a function of cooling time. The average diffusion distance during cooling can be expressed as

$$
\Theta=\int_{0}^{t_{c}} D(t) \partial t
$$




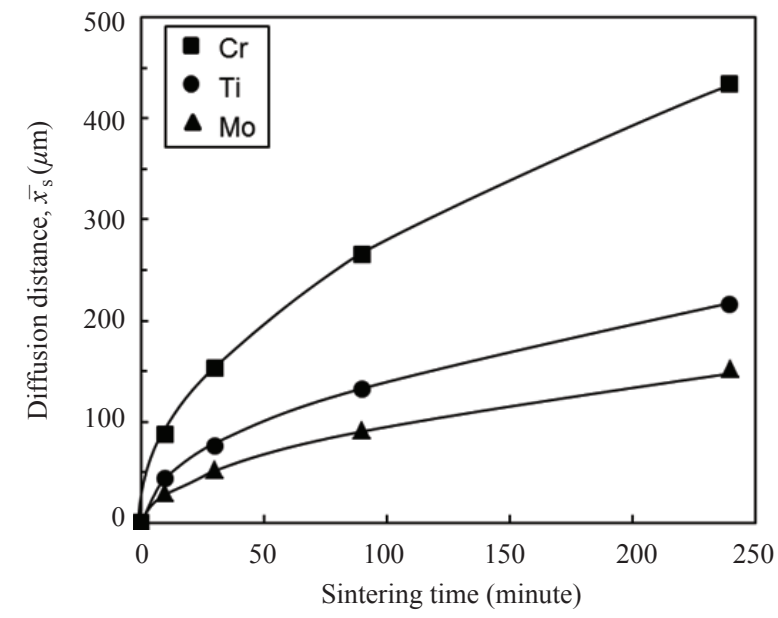

FIGURE 7. The average diffusion distance of each element as a function of sintering time

where $\Theta$ is the average diffusion distance during cooling and $\partial \Theta=D(t) \partial t$. The unit of $\Theta$ is $\mu \mathrm{m}^{2}$.

According to Ganguly (2002) and (2008), the diffusion during cooling is strongly dependent on the cooling time; hence, the diffusion coefficient can be modified by substituting (3) into (1),

$$
D(t)=D_{0} e^{-\frac{Q\left(1+\frac{t}{\lambda}\right)}{\left(R T_{0}\right)}}
$$

Equation (5) can be simplified as follows:

$$
D(t)=\Gamma e^{-t / \sigma}
$$

where $\Gamma=D_{0} e^{-Q /\left(R T_{0}\right)}$ and $\sigma=\lambda\left(\frac{R T_{0}}{Q}\right)$. The average diffusion distance can then be modified by substituting (6) into (4),

$$
\Theta=\int_{0}^{t_{c}} \Gamma e^{-t / \sigma} \partial t
$$

and integrating from to as the time during cooling (Figure 1), to give the average diffusion distance. Finally, the total diffusion distance of each element during furnace cooling can be obtained by substituting the result from (7) into (2),

$$
\bar{x}_{s}=\sqrt{2 \Theta}
$$

The relation between the total diffusion distances of each element during cooling as a function of cooling time was calculated and is shown in Figure 8. In the figure, the top $\mathrm{x}$-axis exhibits the sample's temperature after cooling for certain time, which is shown in the bottom $\mathrm{x}$-axis. The temperature was calculated by (3). It is predicted that the diffusion distance increased as the cooling time was increased. The diffusion distance of $\mathrm{Cr}$ was the highest among the elements. Conversely, the diffusion distance of Mo was the smallest during cooling. The rates of furnace cooling were the same in all samples; thus, the comparative order of total diffusion distances during cooling between elements is $\mathrm{Cr}>\mathrm{Ti}>\mathrm{Mo}$ (Table 4). However, the diffusion distance during furnace cooling was obviously one-tenth or smaller than that during sintering for all elements.

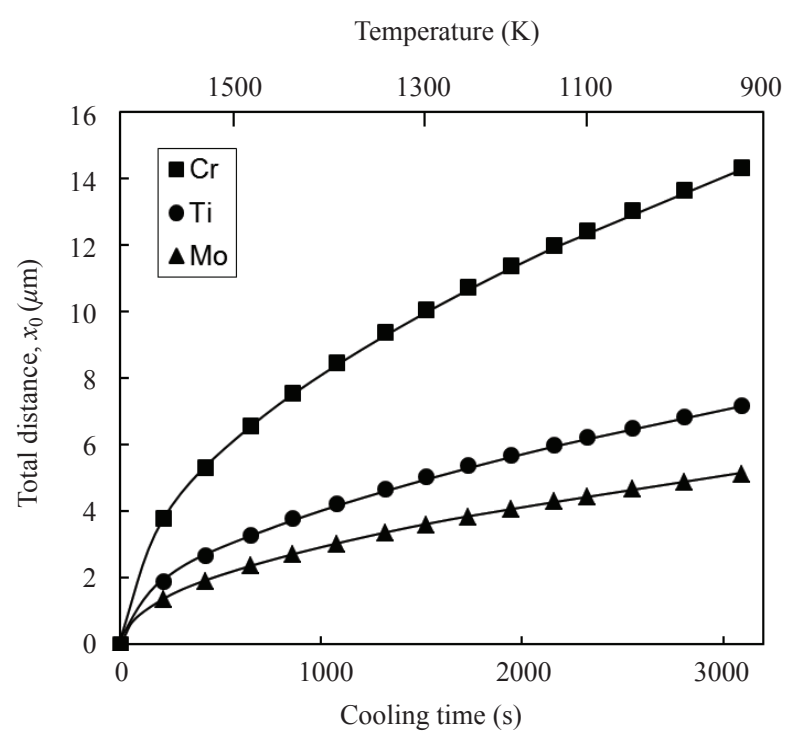

FIGURE 8. Diffusion distance of each element as a function of cooling time in $\beta$-phase with cooling rate $0.23 \mathrm{~K} / \mathrm{s}$

TABLE 4. Total diffusion distance on cooling of each element

\begin{tabular}{cc}
\hline Element & $(\mu \mathrm{m})$ \\
\hline$\beta$-Ti & 7.2 \\
$\mathrm{Cr}$ & 14.3 \\
$\mathrm{Mo}$ & 5.1 \\
\hline
\end{tabular}

Thus, alloying behavior can be observed mostly during sintering. Moreover, the alloying behavior is controlled by the diffusion of Mo atoms because Mo atoms showed the smallest diffusion distance. Therefore, this phenomenon may explain why some Mo particles were still present after sintering for $5.4 \mathrm{ks}$ and furnace cooling (Figures 5 and 6). This calculation agrees well with the observed experimental result that the diffusion of Mo atoms restrains the alloying phenomenon.

\section{CONCLUSION}

Observing the diffusion of alloying elements in Ti- $10 \% \mathrm{Mo}-$ $10 \% \mathrm{Cr}$ alloy during sintering and furnace cooling led to the following conclusions. Alloying and microstructural changes occurred during both sintering and furnace cooling. However, the alloying behavior mostly occurred during sintering. The alloying behavior was controlled by the diffusion of Mo. The Mo and $\mathrm{Cr}$ atoms showed the lowest and highest diffusion distances, respectively, during both sintering and furnace cooling.

\section{ACKNOWLEDGEMENTS}

The authors would like to acknowledge Universiti Kebangsaan Malaysia and the Ministry of Science, Technology, and Innovation for funding this research under Grant Arus Perdana UKM-AP-NBT-14-2010 and ERGS/1/2012/TK04/UKM/02/5, respectively. 


\section{REFERENCES}

Abkowitz, S., Abkowitz, S. \& Fisher, H. 2015. Titanium alloy components manufacture from blended elemental powder and the qualification process. In Titanium Powder Metallurgy: Science, Technology and Applications, edited by Qian, M. \& Froes, F.H. Oxford: Butterworth-Heinemann.

Atkins, P. \& De Paula, J. 2006. Atkins' Physical Chemistry. New York: Oxford University Press.

Balluffi, R.W., Allen, S. \& Carter, W.C. 2005. Kinetics of Materials. New Jersey: John Wiley \& Sons, Inc.

Carman, A., Zhang, L.C., Ivasishin, O.M., Savvakin, D.G., Matviychuk, M.V. \& Pereloma, E.V. 2011. Role of alloying elements in microstructure evolution and alloying elements behaviour during sintering of a near- $\beta$ titanium alloy. Materials Science and Engineering: A 528: 1686-1693.

Fujita, T., Ogawa, A., Ouchi, C. \& Tajima, H. 1996. Microstructure and properties of titanium alloy produced in the newly developed blended elemental powder metallurgy process. Materials Science and Engineering: A 213: 148-153.

Ganguly, J. 2002. Diffusion kinetics in minerals: Principles and applications to tectono-metamorphic processes. European Mineralogical Union Notes in Mineralogy 4(Chapter 10): 271-309.

Hagiwara, M. \& Emura, S. 2003 Blended elemental P/M synthesis and property evaluation of Ti-1100 alloy. Materials Science and Engineering: A 352: 85-92.

Kakani, S.L. 2004. Material Science. New Delhi: New Age International (P) Limited.

Leyens, C. \& Peters, M. 2003. Titanium and Titanium Alloys. Weinheim: WILEY-VCH Verlag GmbH \& Co. KGaA.

Lütjering, G. \& Williams, J.C. 2007. Titanium. 2nd ed. Berlin: Springer-Verlag.

Nakajima, H. \& Koiwa, M. 1991. Diffusion in titanium. ISIJ International 31: 757-766.

Niinomi, M. 2003. Recent research and development in titanium alloys for biomedical applications and healthcare goods. Science and Technology of Advanced Materials 4: 445-454.

Niinomi, M. 2002. Recent metallic materials for biomedical applications. Metallurgical and Materials Transactions A 33: 477-486.
Oliveira, N. \& Guastaldi, A. 2009. Electrochemical stability and corrosion resistance of Ti-Mo alloys for biomedical applications. Acta Biomaterialia 5: 399-405.

Philibert, J. 1991. Atom Movements: Diffusion and Mass Transport in Solids. Les Ulis: Editions de Physique.

Shackelford, J.F. \& Alexander, W. 2010. CRC Materials Science and Engineering Handbook. 3rd ed. Florida: Taylor \& Francis.

Shewmon, P.G. 1989. Diffusion in Solids. 2nd ed. New York: McGraw-Hill.

Syarif, J., Rohmannudin, T.N., Omar, M.Z., Sajuri, Z. \& Harjanto, S. 2013. Stability of the beta phase in Ti-Mo-Cr alloy fabricated by powder metallurgy. Journal of Mining and Metallurgy, Section B: Metallurgy 49: 285-292.

Syarif, J., Rohmannudin, T.N., Omar, M.Z., Sajuri, Z. \& Daud, A.R. 2008. Study on formation of $\beta$ single phase of a Ti-10at $\%$ Mo- $10 \mathrm{at} \% \mathrm{Cr}$ alloy on sintering and solution treatment, Proceedings of the 1st WSEAS International Conference on Materials Science. pp. 48-52.

Yang, Y.F., Luo, S.D., Schaffer, G.B. \& Qian, M. 2011. Sintering of Ti-10V-2Fe-3Al and mechanical properties. Materials Science and Engineering: A 528(22-23): 6719-6726.

Zhang, Y. 2008. Geochemical Kinetics. New Jersey: Princeton University Press.

Junaidi Syarif

University of Sharjah

College of Engineering, Sharjah

UAE

Eko Kurniawan, Tubagus N. Rohmannudin, Mohamad Rasidi Rasani \& Zainuddin Sajuri

Faculty of Engineering and Built Environment

Universiti Kebangsaan Malaysia

43600 UKM Bangi, Selangor Darul Ehsan

Malaysia

*Corresponding author; email: sjunaidi@sharjah.ac.ae

Received: 17 October 2016

Accepted: 25 October 2017 
